\title{
A Comparative Financial Performance Analysis of Some Selected Private Commercial Banks of Ethiopia: A CAMEL Approach
}

\author{
Dereje Birhanie \\ Department of Accounting and Finance, Debre Markos University, Debre Markos, Ethiopia \\ Email address: \\ acc12321dar@gmail.com
}

\section{To cite this article:}

Dereje Birhanie. A Comparative Financial Performance Analysis of Some Selected Private Commercial Banks of Ethiopia: A Camel Approach. International Journal of Accounting, Finance and Risk Management. Vol. 5, No. 4, 2020, pp. 174-183.

doi: $10.11648 /$ j.ijafrm.20200504.11

Received: October 22, 2020; Accepted: November 5, 2020; Published: November 19, 2020

\begin{abstract}
This study was aimed at measuring the financial performance of some selected private banks in Ethiopia. The financial performance of selected banks has been measured by using the five too important components of financial measures; those are capital adequacy, asset quality, management capacity, earning capacity and liquidity of banks. To this end necessary audited financial statements and related disclosures of selected private banks, which were prepared in line with international financial reporting standards for three consecutive years from 2017-2019 have been used. The collected secondary data have been analyzed by using a ratio analysis model. In line with comparison of selected private banks each other, the study revealed the following results. When Capital adequacy is used as a performance measure, comparatively Addis international bank is treated as capitally adequate and safe for creditors and depositors in repaying the loan what it is received. Abay bank, Dashen bank and Abyssinia bank jointly treated as relatively safe and capitally adequate next to Addis international bank. In terms of asset quality, awash international bank relatively treated better in managing credit followed by bank of Abyssinia and Addis international bank. When management efficiency is used as a performance measure of banks, Addis international bank is comparatively efficient in utilizing its assets to generate income a lot as compared to the remaining banks under study. In its earning quality, awash international bank has selected as the leader of the remaining banks. The study also concludes the performance of banks in terms of liquidity as one component of CAMEL, based on the analysis Abay bank outperforms the remaining banks.
\end{abstract}

Keywords: Asset Quality, Capital Adequacy, Earning capacity, Management Efficiency, Liquidity

\section{Introduction}

Countries whether developing or developed, will achieve its economic growth when the business is succeeded. Business will be succeeded when they operate efficiently and effectively and maximize the wealth of the owners. For efficient operation, financial information plays an important role in making planning and controlling decisions. This information is obtained from the financial statement of the firm. Firms prepare financial statements to provide it for internal users to make decisions that will enable them to plan for future and take corrective actions based on actual results and for external users i,e investors, banks, creditors, government, and other interested users.

At the very outset, banks are established for and play an important role in improving the country's economy via promoting capital formation through mobilization of funds, encouraging innovation, monetization and influencing the economic activity of the country through the channelization of the mobilized funds in to different investment areas.

Financial statement analysis refers reviewing and analyzing a company's financial statements to make economic decisions and generate income in the future. The statements that will be analyzed includes statement of profit and loss, statement of financial position, statements of changes in equity, statements of cash flow and other additional disclosures. Financial statement analysis is a means of evaluating the firm's performance, risk, financial 
health and firm's future prospects [1].

Financial performance is the degree to which financial objectives being or has been accomplished. It is a measure of firms operation result and firms overall financial health in terms of money. Financial performance analysis includes analysis and interpretation of financial statements by triangulating the profitability and soundness of the business. [2].

The company's financial statement should be analyzed to provide the clear picture of the company to different interested users that may use it for the purpose of analyzing the performance of the firm. The financial performance of the firm can be depicted through different means of analysis which includes vertical analysis, horizontal analysis, cross sectional analysis. This study is too important for providing relevant outlook for different users of information to make relevant decisions. Those users might be investors, creditors, and other fund suppliers. Investors may use this study to decide, to which bank shall they commit their funds or invest their funds based on the analysis. Creditors also use the study findings to which bank they will extend loan.

\section{Statement of the Problem}

The banking system in Ethiopia marked in the beginning of $20^{\text {th }}$ century, when the bank of Abyssinia was established by emperor Minillik II in 1906. As the time is passed this bank was shaped by different ruling party of Ethiopia. Subsequently different private commercial banks were inaugurated and participated in the financial sector of the country. As the role of financial institutions, private banks also play a crucial role in promoting saving and investment via mobilization of funds in the form of deposit and channelization of it in different investment opportunities. Even if banks have unreserved benefits in promoting economic growth, they faced with different challenges. According to Andualem in his investigation reflected that, the major challenges faced with banks are persistent inflation, lack of skilled man power in the market, poor infrastructure [3].

Evaluating the performance of banks is just an effective measure and indicator for smoothness of the economic activities. So, banks performance can be measured by analyzing the information that is prepared by banks or simply the financial statements.

According to Corporate Finance Institute review, banks in Ethiopia faced with foreign exchange related issues and local political unrest. These challenges are expected to have an impact on the financial performance of private banks. Since the provision of financial information is vital for many interested users to make their decision timely, this study aimed to evaluate the performance of some selected private commercial banks in Ethiopia [4].

\section{Objective of the Study}

\subsection{General Objective}

The general objective of this study is to analyze the financial performance of private commercial banks in Ethiopia.

\subsection{Specific Objective}

Specifically the study aimed at:

a. To examine the capital adequacy of the of selected banks

b. To evaluate the asset quality of banks

c. To interrogate the management efficiency of the selected banks

d. To examine the earning capacity of banks

e. To evaluate the liquidity of selected banks

\section{Review of Related Literature}

\subsection{Empirical Evidence}

Financial performance implicates that the achievement of the purpose for establishment. Financial performance of a company is being analyzed by using different methods. It is obvious that, banks which earn a positive profit during the operation period may not be treated as financially sound and healthy, because one of the aim of any business to maximize the wealth of share holders other than maximizing a short term profit. So applying a profitability measure alone may not be sound for measuring financial performance of firms in general and banks in particular.

Teshome, in his study entitled Evaluating the Financial Performance of Ethiopian Banks Using Financial IndicatorsA Case Study on Dashen Bank by using a five year data from 2011-2015. In his study he found that, in the operation period 2015 the bank faced with poor performance when it is compared to the previous three periods (from 2012-2014), and the bank was not much loaned up as well as its liquidity is in a good position. In addition to this, the liquidity ratio was improved from year to year [5].

kiran on his study investigated by using seven public banks and four private banks in india under the title of CAMEL model analysis of selected public and private sector banks in india concluded that, private banks outperforms the public banks and the first four ranks which is made based on the CAMEL elements goes to the private sector banks [6]. Aguenaous, Lahrech. A, bounakaya s,. Investigated a study to show the effects of CAMEL ratios on the efficiency of the Moroccan banks performance. On their study, they found that, the performances of Moroccan banks efficiency were better for the period between 2004 and 2014 and they also reflect the effects of CAMEL elements in the efficiency of the banks. The finding shows capital adequacy, asset quality, management efficiency, and liquidity has a positive impact on efficiency, where as earning performance have been insignificant for efficiency [7].

Chowdhury on his study entitled, a comparative study of profitability analysis in banking sector of Bangladesh, founds that, a substantial rise in a collection of loans adversely affects the ROA and ROE of banking industry. Behind this Chowdhury also reflects that, a reduction in credit supply by an individual bank would reduce its market share and profit [8]. 
A study conducted by Abdullah, entitled an empirical analysis of liquidity, profitability and solvency of Bangladesh banks by using a Z-score model, from the investigated 29 banks in Bangladesh, only 7 banks are in a healthy financial position and the remaining 22banks are found insolvent for the period under study [9]. Ali Under the title, bank profitability and its determinants in Pakistan: a panel data analysis after financial crisis, the banks in Pakistan were managed well to avoid an external factors like inflation and GDP in the profitability of banks [10].

Trofimov, Ivan. D, etal on their study entitled determinants of commercial banks profitability in Malaysia, founds that non performing loans and the cost efficiency have a significant negative relationship with commercial banks performance in Malaysia. However bank size has been founded to have a significant positive relation with commercial banks performance in Malaysia [11].

\subsection{CAMEL Model}

This model aimed at measuring the performance of banks by using the key terms what are included in the word CAMEL which are capital adequacy, asset quality, management efficiency, earning capacity and liquidity. This model originally developed in the United States in 1970 to classify the banks over all condition. This model is applied to every bank in the United States and credit unions and it is also implemented outside United States by various banking supervisory regulators. The model was revised in 1996 to add the other component of CAMEL to evaluate the performance of banks called sensitivity [12].

The core components under this approach which are abbreviated as CAMEL are: capital adequacy, asset quality, management efficiency earning capacity, and liquidity.

\section{Study Methods}

\subsection{Study Approach}

To answer the basic questions, the study applied a quantitative research approach by infracting the ratios related to the performance measures. In this approach, necessary secondary data have been collected from the annual report of selected five private commercial banks, and being analyzed by using a ratio CAMEL analysis.

\subsection{Types and Sources of Data}

In achieving the study objectives, the researcher used secondary data. The data have been collected from the annual reports of five selected private commercial banks and related documents. From the annual financial reports, the researcher used a three year financial statement which are prepared in line with international financial reporting standard (IFRS) from 2017-2019.

\subsection{Sampling Design and Sample Size}

In undertaking this study the researcher considers all private commercial banks as a target population those are 17 in number. From those 17 private commercial banks the researcher purposively picked 5 banks (Abay Bank, Abyssinya Bank, Dahen Bank, Addis International Bank, and Awash international Bank) for investigation.

\subsection{Methods of Data Presentation and Analysis}

After necessary data were collected, it was presented by using tables. Data were analyzed by using A CAMEL (capital adequacy, asset quality, management efficiency, earning capacity and liquidity) model. Based on the aforementioned model, ratios were computed for each element of the model and a comparison was made to judge which bank have been performed better during the period investigated. A ratio analysis; liquidity, activity, solvency and profitability analysis were made. In doing so, the researcher have been made the group average ranking so as to make comparison between banks.

\section{Discussions and Findings}

\subsection{Capital Adequacy of the Selected Banks}

Capital adequacy refers the amount of capital funds that the bank or other financial institutions expected to have as required by the financial regulator of the country. It is a measure of banks and other financial institutions ability to pay its debts if people or organizations are unable to pay back the money they have borrowed from bank.

The capital adequacy of firms can be measured by equity to asset ratio, debt to equity ratio. Capital adequacy ratio advances to total asset ratio. The capital adequacy of banks under investigation are presented and analyzed in the following table.

Capital adequacy ratio (CAR): this ratio measures the adequacy of the firms in case of unexpected risk for creditors and depositors. This ratio is computed by dividing the sum of firm's tier 1 and tier 2 capitals to a risk weighted assets of banks. A higher capital adequacy ratio indicates the bank as a more safe and interesting.

Table 1. Capital adequacy ratio.

\begin{tabular}{lllll}
\hline CAR & $\mathbf{2 0 1 7}$ & $\mathbf{2 0 1 8}$ & $\mathbf{2 0 1 9}$ & Average \\
\hline Abay & $17.80 \%$ & $17.18 \%$ & $18.94 \%$ & 0.179733333 \\
Abyssinia & $15.30 \%$ & $15.62 \%$ & $14.66 \%$ & 0.151933333 \\
Awash & $18 \%$ & $13 \%$ & $12 \%$ & 0.143333333 \\
Addis & $21 \%$ & $16 \%$ & $20 \%$ & 0.19 \\
Dashen & $26 \%$ & $19 \%$ & $18 \%$ & 0.21 \\
\hline
\end{tabular}

Source: Annual report of selected banks from 2017-2019.

This table tells us, Dashen bank sets at the top of the banks under study with an average capital adequacy ratio of 0.21 , followed by Addis international bank and Abay bank with a respective capital adequacy ratio of 0.19 and 0.1797 respectively.

Loans to asset ratio: This ratio measures the capital adequacy of the bank by reviewing the aggressiveness of the 
bank in extending loan. It can be computed by dividing the total loans extended during the period by the total asset of the bank. The higher ratio implies the better capital adequacy of the firm.

Table 2. Loan -to -Asset ratio.

\begin{tabular}{|c|c|c|c|c|}
\hline \multicolumn{5}{|c|}{ Loan-to-asset ratio } \\
\hline & 2017 & 2018 & 2019 & average \\
\hline Abay & 0.490082948 & 0.478574141 & 0.502914976 & 0.490524022 \\
\hline Abyssinia & 0.538461125 & 0.555949848 & 0.596045037 & 0.563485337 \\
\hline Dashen & 0.496954503 & 0.507591483 & 0.575721971 & 0.526755986 \\
\hline Addis & 0.45441885 & 0.483480037 & 0.480249638 & 0.472716175 \\
\hline Awash & 0.55947093 & 0.561789786 & 0.627786505 & 0.583015741 \\
\hline
\end{tabular}

Source: Annual report of banks from 2017-2019, researchers computation.

Based on the table stated above, the ranking of selected banks under investigation revealed that, Awash international bank ranked first with a higher average loan to deposit ratio of 0.583 followed by Abyssinia bank, Dashen bank, Abay bank and Addis bankwith a loan to asset ratio of $0.563,0.526$, 0.49 , and 0.472 respectively.
Debt- to-equity ratio: This ratio measures the proportion of debt hold by the bank for each unit of equity. It can be computed by dividing total liability by total equity. A higher ratio indicates less protection for the creditors and depositors in its banking system.

Table 3. Debt-to-Equity ratio.

\begin{tabular}{lllll}
\hline D/Eratio & & & & \\
\hline & $\mathbf{2 0 1 7}$ & $\mathbf{2 0 1 8}$ & $\mathbf{2 0 1 9}$ & Average \\
\hline ABAY & 5.650305875 & 5.834046862 & 5.147138174 & 5.543830304 \\
Abyssinia & 6.749339726 & 6.533646978 & 6.937648701 & 6.740211802 \\
Dashen & 5.882882445 & 6.74303563 & 8.444245551 & 3.023387875 \\
Addis & 3.567276583 & 3.692070078 & 3.961035772 & 6.740127478 \\
Awash & 6.379520272 & 7.508395998 & 6.743119671 & 6.87701198 \\
\hline
\end{tabular}

Source: Annual report of banks from 2017-2019, researchers computation.

Based on the debt to equity ratio reflected in table 3 , Addis international bank set as the first bank which protects against its creditors and depositors with its debt to equity ratio of 3.74 followed by Abay bank, abyssinya bank, awash bank and dashen bank with their debt-to -equity ratio of 5.543,

\section{$6.740,6.877$, and 7.023 respectively.}

The results of the group average for table 4, ratios revealed the following conclusions for the comparative capital adequacy of banks are presented and analyzed as follows:

Table 4. Composite capital adequacy.

\begin{tabular}{|c|c|c|c|c|c|c|c|c|}
\hline Banks & Capital adeq & & Loan-asset & & Debt- to- equity & & Group rank & \\
\hline & Average & Rank & Ratio & Rank & Ratio & Rank & Average & Rank \\
\hline ABAY & 0.179733333 & 3 & 0.490524022 & 4 & 5.543830304 & 2 & 3 & 2 \\
\hline Abyssinia & 0.151933333 & 4 & 0.563485337 & 2 & 6.740211802 & 3 & 3 & 2 \\
\hline Dashen & 0.21 & 1 & 0.526755986 & 3 & 7.023387875 & 5 & 3 & 2 \\
\hline Addis & 0.19 & 2 & 0.472716175 & 5 & 3.740127478 & 1 & 2.6667 & 1 \\
\hline Awash & 0.143333333 & 5 & 0.583015741 & 1 & 6.87701198 & 4 & 3.3333 & 3 \\
\hline
\end{tabular}

Source: Annual report of banks from 2017-2019, researchers computation.

Based on the three capital adequacy ratio, the above table reflects that Addis international bank is ranked first with an average group rank value of 2.6667 followed by Abay bank, Dashen bank, and Abyssinia bank jointly held the second rank with a group rank value of 3 . When it is concluded, the whole selected banks are relatively similar.

\subsection{Asset Quality of the Selected Banks}

Asset quality rating refers the evaluation of credit risk associated with a particular asset. The asset quality of the banks can be measured using gross non-performing loan -to-gross loan ratio, non performing loan -to- total asset ratio, investment -to- asset ratio and so on. Under this study the asset quality of banks are measured by using the following ratios.

Non-performing loan-to- gross loan ratio:-this ratio measures how much of funds extended are under risk of default in relation to the total loan made. Non- performing loan refers the amounts of loan extended to customers and past due more than 60 days. This ratio can be calculated by dividing the total non-performing loan to the total loans of the bank. A lower ratio indicates the efficiency of the bank in credit management. The following table indicates the nonperforming loan-to-gross loan ratio for the five selected private commercial banks of Ethiopia. 
Table 5. Non-performing loan-to-gross loan ratio.

\begin{tabular}{|c|c|c|c|c|}
\hline NPL-L ratio & 2017 & 2018 & 2019 & Average \\
\hline Abay & 0.015923951 & 0.03359878 & 0.030353224 & 0.02662535 \\
\hline Abyssina & 0.014002896 & 0.01319274 & 0.035277285 & 0.02082425 \\
\hline Dashen & 0.034952878 & 0.03450741 & 0.030148473 & 0.03320298 \\
\hline Addis & 0.003191914 & 0.02054792 & 0.05142212 & 0.02505395 \\
\hline Awash & 0.019521586 & 0.01877284 & 0.013411673 & 0.01723536 \\
\hline
\end{tabular}

Source: Annual report of banks from 2017-2019, researcher computation.

The above table tells that, Awash international bank set at the top of selected banks and ranked first with a lower nonperforming loan-to-gross loan ratio of 0.013 , followed by Abyssiniabank, and Addis bank with aNPL-L ratio of 0.021 approximately and 0.025 . Dashen bank ranked last with a relatively higher NPL-L ratio of 0.033 .
Non-performing loan -to- total asset ratio (NPL-TA): This ratio measures the amount of assets under risk of default in relation to the total resources controlled by the bank. This ratio will be computed by dividing non-performing assets of the bank to the total asset of the bank. The ratios of the selected banks are depicted as follows:

Table 6. NPL-TA ratio.

\begin{tabular}{|c|c|c|c|c|}
\hline NPL-TA ratio & 2017 & 2018 & 2019 & Average \\
\hline Abay & 0.00780407 & 0.0160796 & 0.0152651 & 0.013049555 \\
\hline Abyssia & 0.00754005 & 0.0073342 & 0.0210261 & 0.011967116 \\
\hline Dashen & 0.01736999 & 0.0175156 & 0.0173578 & 0.017414274 \\
\hline Addis & 0.00145046 & 0.0099345 & 0.0246955 & 0.012026815 \\
\hline Awash & 0.01092176 & 0.0105469 & 0.0084196 & 0.009962606 \\
\hline
\end{tabular}

Source: Annual report of banks from 2017-2019, researcher computation.

Table 6 demonstrates that, Awash international bank leads the remaining banks under investigation with a lower nonperforming loan to total asset ratio of 0.0099 , followed by
Abyssinia bank, and Addis international bank with an average NPL-TA ratio of 0.0119 and 0.0120 respectively. The composite asset quality ratio reflected as follows.

Table 7. Composite asset quality.

\begin{tabular}{|c|c|c|c|c|c|c|}
\hline \multicolumn{7}{|c|}{ composite asset quality ranks } \\
\hline & \multicolumn{2}{|l|}{ NPL-L } & \multicolumn{2}{|l|}{ NPL-TA ratio } & \multicolumn{2}{|c|}{ group rank } \\
\hline & Ratio & Rank & Ratio & Rank & average & Rank \\
\hline Abay & 0.02662535 & 4 & 0.01304955 & 4 & 4 & 4 \\
\hline Abyssinia & 0.02082425 & 2 & 0.01196711 & 2 & 2 & 2 \\
\hline Dashen & 0.03320293 & 5 & 0.01741424 & 5 & 5 & 5 \\
\hline Addis & 0.02505395 & 3 & 0.01202685 & 3 & 3 & 3 \\
\hline Awash & 0.017235366 & 1 & 0.00996266 & 1 & 1 & 1 \\
\hline
\end{tabular}

Source: Annual report of banks from 2017-2019, researcher computation.

The group average for the two asset quality ratio which is depicted in the table above, clarifies that, awash international bank gets the first rank with group average rank of 1, followed by bank of Abyssinia and Addis international bank with group average rank of 2 and 3 respectively.

\subsection{Management Efficiency}

This component of CAMEL helps us to evaluate the banks management efficiency in making relevant decisions with proper resource utilization. Management efficiency of banks can be measured by using asset utilization ratio (AUR), loanto-deposit ratio (LDR), operating expense ratio and so on. In this study, the efficiency of the management was evaluated by using the following ratios.

Asset utilization ratio (AUR): measures the efficiency of the firm in using its assets to generate revenue aimed at reaching sufficient profitability level. It can be computed by dividing the total operating income to average total asset. A higher ratio indicates, the more efficient a company is in generating revenue from its assets. The result presented as follows:

Table 8. Asset utilization ratio (AUR).

\begin{tabular}{lllll}
\hline ATOR & $\mathbf{2 0 1 7}$ & $\mathbf{2 0 1 8}$ & $\mathbf{2 0 1 9}$ & Average \\
\hline ABAY & 0.08615297 & 0.091196834 & 0.09861612 & 0.091988637 \\
abyssinya & 0.082166238 & 0.076656078 & 0.078036702 & 0.078953006 \\
Dashen & 0.073811053 & 0.067149107 & 0.067134776 & 0.069364979 \\
addis & 0.097992493 & 0.083799782 & 0.094777209 & 0.092189828 \\
Awash & 0.08045808 & 0.082387139 & 0.091571511 & 0.084805577 \\
\hline
\end{tabular}

Source: Annual report of banks from 2017-2019, researcher computation. 
The above table shows that, Addis international bank leads the remaining bank with its asset utilization approximate value of 0.0922 , followed by Abay bank and awash international bank with a ratio of 0.0919 , and 0.0848 . The result tells us, Addis bank is efficient in utilizing its assets to generate income a lot as compared to the remaining banks under study.

\subsection{Earning Quality}

The quality of earnings refers to the proportion of income attributable to the core operating activities of the firm. The quality of earnings or earning capacity of firms can be measured by using return on asset ratio, return on equity ratio, net interest margin, and so on. In this study the researcher evaluates the quality of earnings for the banks by using the following ratios.

Return on asset (ROA): measures how the firm assets are profitable in generating income. This ratio is computed by dividing net income to total asset. The result for the selected banks are presented as follows:

Table 9. Return on asset (ROA).

\begin{tabular}{|c|c|c|c|c|}
\hline ROA & 2017 & 2018 & 2019 & Average \\
\hline ABAY & 0.021867373 & 0.025718739 & 0.033203968 & 0.026930027 \\
\hline abyssinya & 0.019734841 & 0.017596829 & 0.019774154 & 0.019035274 \\
\hline Dashen & 0.022633548 & 0.020450111 & 0.018086116 & 0.020389925 \\
\hline addis & 0.027772992 & 0.026824285 & 0.028878334 & 0.027825204 \\
\hline Awash & 0.025056696 & 0.027003367 & 0.032596193 & 0.028218752 \\
\hline
\end{tabular}

Source: Annual report of banks from 2017-2019, researcher computation.

As indicated in the table above, awash international bank performs better with a relatively higher ROA of 0.0282 , followed by Addis international bank, and Abay ban with a ROA of 0.0278 , and 0.0269 respectively.

Return on equity (ROE): measures, how much net income is earned by using the equity capital of the firm. ROE of the firm is calculated by dividing net income to the common stockholders' equity capital. A higher ROE indicates the better earning quality of the firm. The ROA of the selected private banks are summarized below.

Table 10. Return on equity (ROE.).

\begin{tabular}{lllll}
\hline ROE & $\mathbf{2 0 1 7}$ & $\mathbf{2 0 1 8}$ & 2019 & Average \\
\hline ABAY & 0.145424722 & 0.175763067 & 0.204109378 & 0.175099056 \\
Abyssinia & 0.152931986 & 0.132568294 & 0.156960286 & 0.147486855 \\
Dashen & 0.155784048 & 0.158345934 & 0.173903071 & 0.162677685 \\
Addis & 0.126846934 & 0.125861427 & 0.14326645 & 0.131991604 \\
Awash & 0.184906396 & 0.229755343 & 0.252396221 & 0.222352653 \\
\hline
\end{tabular}

Source: Annual report of banks from 2017-2019, researcher computation.

Table 8 aboverevealed that, awash international bank sets at the top of banks understudy with its higher ROE ratio of 0.2223 , followed by Abay bank and Dashen bank with a ROE of 0.1750 and 0.1626 respectively.

Net interest margin (NIM): this ratio measures the difference between the interest income by banks and the amount of interest paid to their creditors, in relation to their earning assets. The result can be calculated by dividing net interest income to earning assets. A higher net interest margin is favorable for banks and indicates a better earning quality for banks. The following table summarizes the NIM of banks under investigation.

Table 11. Net interest margin (NIM).

\begin{tabular}{|c|c|c|c|c|}
\hline NIM & 2017 & 2018 & 2019 & Average \\
\hline ABAY & 0.053392959 & 0.058403404 & 0.056032124 & 0.055942829 \\
\hline Abyssinia & 0.052129832 & 0.068847259 & 0.06388258 & 0.06161989 \\
\hline Dashen & 0.053585162 & 0.054408105 & 0.053033445 & 0.053675571 \\
\hline Addis & 0.050420308 & 0.053563858 & 0.05323192 & 0.052405362 \\
\hline Awash & 0.063787103 & 0.068709479 & 0.065858401 & 0.066118328 \\
\hline
\end{tabular}

Source: Annual report of banks from 2017-2019, researcher computation.

The above table demonstrates that, awash international bank ranked first with its higher net interest margin of 0.0661 . Abyssinia bank and Abay bank ranked second and third with their respective NIM of 0.0616, and 0.0559.

The composite earning quality group rank of the selected private company revealed the following information.

Table 12. Composite earning quality

\begin{tabular}{llllllll}
\hline ROA ratio & & & ROE ratio & & NIM ratio & group rank \\
\hline Banks & Ratio & Rank & Ratio & Rank & Ratio & Rank & Average \\
\hline ABAY & 0.026930027 & 3 & 0.175099056 & 2 & 0.055942829 & 3 \\
\hline
\end{tabular}




\begin{tabular}{|c|c|c|c|c|c|c|c|c|}
\hline \multicolumn{2}{|l|}{ ROA ratio } & \multicolumn{2}{|r|}{ ROE ratio } & \multicolumn{2}{|r|}{ NIM ratio } & \multicolumn{3}{|c|}{ group rank } \\
\hline Banks & Ratio & Rank & Ratio & Rank & Ratio & Rank & Average & Rank \\
\hline abyssinia & 0.019035274 & 5 & 0.147486855 & 4 & 0.06161989 & 2 & 3.67 & 3 \\
\hline Dashen & 0.020389925 & 4 & 0.162677685 & 3 & 0.053675571 & 4 & 2.67 & 2 \\
\hline addis & 0.027825204 & 2 & 0.131991604 & 5 & 0.052405362 & 5 & 4 & 4 \\
\hline Awash & 0.028218752 & 1 & 0.222352653 & 1 & 0.066118328 & 1 & 1 & 1 \\
\hline
\end{tabular}

Source: Annual report of banks from 2017-2019, researcher computation.

The above table clearly summarizes the composite earning quality which is measured by using the 3 different ratios. Based on this ratio banks are ranked for reflecting the better performing bank. Based on this the researcher concludes that, awash international bank is ranked first with a group rank of 1, whereas Abay bank and Dashen bank jointly held the second rank with an average rank of 2.67, followed by Bank of abyssinya with an average rank of 3.67. Based on this composite rank, awash international bank performs better in earning profit by using its assets, equity capital, and have the better net interest margin as it is compared to the remaining banks under the study.

\subsection{Liquidity}

One of the component which enables measuring the performance of banks referred liquidity. Liquidity measures how firms are able to meet its financial obligations as they come due. Liquidity of banks is measured by loan-to-deposit ratio, cash-to-deposit ratio, current ratio, etc. However measuring the liquidity of banks is somehow challenging because much of their assets are composed of cash and this cash is subjected to the extension of credit. In this study, the researcher measures the liquidity of the selected banks by using the following ratios.

Cash-to-deposit ratio: this ratio measures how much cash is hold by the bank to pay back the deposits made by customers and other banks. The ratio will be computed by dividing cash to total deposit. A higher ratio is an indicator of strong liquidity. In this study the cash -to- deposit ratio for the selected banks are presented below.

Table 13. Cash-to-deposit ratio.

\begin{tabular}{|c|c|c|c|c|}
\hline CDR & 2017 & 2018 & 2019 & Average \\
\hline ABAY & 0.289718228 & 0.308356704 & 0.281331717 & 0.293135549 \\
\hline Abyssinia & 0.165375663 & 0.174129254 & 0.139119627 & 0.159541515 \\
\hline Dashen & 0.188695743 & 0.195656685 & 0.136174762 & 0.173509064 \\
\hline Awash & 0.229160628 & 0.267708702 & 0.190730527 & 0.229199952 \\
\hline
\end{tabular}

Source: Annual report of banks from 2017-2019, researcher computation.

The above table tells us, Addis international bank has ranked first with a relatively higher cash to deposit ratio of 0.3629, followed by Abay bank and awash international bank with a cash-to-deposit ratio of 0.2931 and 0.2292 respectively. Based on this ratio the researcher generalized that Addis international bank has a relatively better liquidity as compared to that of the remaining selected banks.

Loan to deposit ratio (LDR): measures the liquidity of the bank by using the loans and advances in relation to the total deposit made by customers and other bank. A higher loan to deposit ratio indicates the firms' poor liquidity. A relatively lower loan-to deposit ratio is favorable

Table 14. Loan to deposit ratio (LDR).

\begin{tabular}{lllll}
\hline LDR & $\mathbf{2 0 1 7}$ & $\mathbf{2 0 1 8}$ & $\mathbf{2 0 1 9}$ & Average \\
\hline ABAY & 0.673758958 & 0.623114256 & 0.655020877 & 0.650631363 \\
abyssinya & 0.66996159 & 0.689330533 & 0.728579601 & 0.695957241 \\
Dashen & 0.642428056 & 0.640722015 & 0.723727419 & 0.668959163 \\
addis & 0.680468772 & 0.685096875 & 0.671092286 & 0.678885978 \\
Awash & 0.729444245 & 0.714570157 & 0.785947382 & 0.743320595 \\
\hline
\end{tabular}

Source: Annual report of banks from 2017-2019, researcher computation.

Table 14 demonstrates that, Abay bank held the first rank with a relatively lower loan to deposit value of 0.6506 , this implicates that for each birr customer deposit the bank extends a 0.6506 cent loan. Dashen bank and Addis international bank held the second and third rank with a loan to deposit ratio of 0.6689 , and 0.6788 respectively.

The following table summarizes the composite ranking for liquidity of the selected banks.

Table 15. Composite liquidity of banks.

\begin{tabular}{llllll}
\hline & Cash-to-deposit ratio & & loan-to-deposit ratio & group rank \\
\hline Banks & Ratio & Rank & Average & rank & Average \\
\hline ABAY & 0.293135549 & 2 & 0.650631363 & 1 & 1.5 \\
abyssinya & 0.159541515 & 5 & 0.695957241 & 4 & 4.5 \\
Dashen & 0.173509064 & 4 & 0.668959163 & 2 & 3 \\
\hline
\end{tabular}




\begin{tabular}{llllll}
\hline & Cash-to-deposit ratio & & loan-to-deposit ratio & group rank \\
\hline Banks & Ratio & Rank & Average & rank & Average \\
\hline addis & 0.362985028 & 1 & 0.678885978 & 3 & 2 \\
Awash & 0.229199952 & 3 & 0.743320595 & 5 & 4 \\
\hline
\end{tabular}

Source: Annual report of banks from 2017-2019, researcher computation.

Table 15, revealed that Abay bank ranked first with an average rank value of 1.5 followed by Addis international bank and Dashen bank with a respective average group rank of 2 and 3 respectively. Based on this composite ranking of liquidity, comparatively Abay bank is liquid when it is compared with that of the banks investigated.

\section{Conclusions}

Banks are the leading growing financial institutions in Ethiopia with their unreserved role in promoting investment and financing different projects. Analyzing and evaluating the performances of banks yields a lot in the provision of information to investors and interested users. Based on the result discussed in the previous chapter, the researcher concluded the performance of the banks by using the five components abbreviated as CAMEL (capital adequacy, asset quality, management efficiency, earning quality, and liquidity) as follows:

Capital adequacy, in this performance measure, comparatively Addis international bank is treated as capitally adequate and safe for creditors and depositors in repaying the loan what it is received. In terms of asset quality, awash international bank relatively treated better in managing credit followed by bank of Abyssinia and Addis international bank. The performance of banks measured by management efficiency, Addis international bank is comparatively efficient in utilizing its assets to generate income a lot as compared to the remaining banks under study. In its earning quality, awash international bank has selected as the leader of the remaining banks. The study also concludes the performance of banks in terms of liquidity as one component of CAMEL, based on the analysis Abay bank outperforms the remaining banks.

\section{Appendix}

Table 16. Total Asset 2017-2019

\begin{tabular}{llll}
\hline TA & & & \\
\hline & $\mathbf{2 0 1 7}$ & $\mathbf{2 0 1 8}$ & $\mathbf{2 0 1 9}$ \\
\hline Abay & $8,692,402,000$ & $12,325,060,000$ & $15,106,297,000$ \\
Abyssinia & $25,882,043,000$ & $31,983,036,000$ & $39,294,425,000$ \\
Dashen & $36,000,366,000$ & $45,425,378,000$ & $56,218,426,000$ \\
Addis & $3,441,653,000$ & $4,209,059,000$ & $5,514,861,000$ \\
Awash & $40,026,791,000$ & $55,268,107,000$ & $74,635,373,000$ \\
\hline
\end{tabular}

Table 17. Total Liability 2017-2019.

\begin{tabular}{llll}
\hline TL & & & \\
\hline & $\mathbf{2 0 1 7}$ & $\mathbf{2 0 1 8}$ & $\mathbf{2 0 1 9}$ \\
\hline Abay & $7,385,334,000$ & $10,521,581,000$ & $12,648,845,000$ \\
Abyssinya & $22,542,140,000$ & $27,737,677,000$ & $34,344,039,000$ \\
Dashen & $30,769,946,000$ & $39,558,767,000$ & $49,371,646,000$ \\
Addis & $2,688,107,000$ & $3,312,001,000$ & $4,403,226,000$ \\
Awash & $34,602,754,000$ & $48,772,393,000$ & $64,996,445,000$ \\
\hline
\end{tabular}

Table 18. Cash.

\begin{tabular}{llll}
\hline Cash & & & \\
\hline & $\mathbf{2 0 1 7}$ & $\mathbf{2 0 1 8}$ & $\mathbf{2 0 1 9}$ \\
\hline Abay & $1,831,811,000$ & $2,918,932,000$ & $3,262,993,000$ \\
Abyssinya & $3,440,128,000$ & $4,491,584,000$ & $4,472,202,000$ \\
Dashen & $5,254,860,000$ & $7,041,058,000$ & $6,089,941,000$ \\
Addis & $928,443,000$ & $1,036,498,000$ & $1,326,238,000$ \\
Awash & $7,035,196,000$ & $11,632,312,000$ & $11,370,601,000$ \\
\hline
\end{tabular}

Table 19. Deposit.

\begin{tabular}{llll}
\hline & Deposit & & \\
\hline & $\mathbf{2 0 1 7}$ & $\mathbf{2 0 1 8}$ & $\mathbf{2 0 1 9}$ \\
\hline Abay & $6,322,733,000$ & $9,466,089,000$ & $11,598,383,000$ \\
Abyssinya & $20,801,900,000$ & $25,794,540,000$ & $32,146,449,000$ \\
Dashen & $27,848,323,000$ & $35,986,800,000$ & $44,721,510,000$ \\
Addis & $2,298,345,000$ & $2,970,377,000$ & $3,946,566,000$ \\
Awash & $30,699,846,000$ & $43,451,378,000$ & $59,616,052,000$ \\
\hline
\end{tabular}


Table 20. Loan and advances.

\begin{tabular}{llll}
\hline & loan & & $\mathbf{2 0 1 9}$ \\
\cline { 2 - 4 } & $\mathbf{2 0 1 7}$ & $\mathbf{2 0 1 8}$ & $7,597,183,000$ \\
\hline Abay & $4,259,998,000$ & $5,898,455,000$ & $23,421,247,000$ \\
Abyssinia & $13,936,474,000$ & $17,780,964,000$ & $32,366,183,000$ \\
Dashen & $17,890,544,000$ & $23,057,535,000$ & $2,648,510,000$ \\
Addis & $1,563,952,000$ & $2,034,996,000$ & $46,855,080,000$ \\
Awash & $22,393,826,000$ & $31,049,058,000$ & \\
\hline
\end{tabular}

Table 21. Net operating income.

\begin{tabular}{llll}
\hline & net operating income & \\
\cline { 2 - 4 } & $\mathbf{2 0 1 7}$ & $\mathbf{2 0 1 8}$ & $\mathbf{2 0 1 9}$ \\
\hline ABAY & $636,760,000$ & $895,825,000$ & $1,300,455,000$ \\
Abyssinia & $1,713,680,000$ & $2,099,495,000$ & $2,632,660,000$ \\
Dashen & $2,329,604,000$ & $2,825,521,000$ & $3,426,251,000$ \\
Addis & $288,911,000$ & $343,484,000$ & $448,672,000$ \\
Awash & $2,723,032,000$ & $3,915,404,000$ & $5,854,426,000$ \\
\hline
\end{tabular}

Table 22. Net interest margin.

\begin{tabular}{llll}
\hline NII & $\mathbf{2 0 1 7}$ & $\mathbf{2 0 1 8}$ & $\mathbf{2 0 1 9}$ \\
\hline ABAY & $337,962,000$ & $515,301,000$ & $635,286,000$ \\
Abyssinia & $1,001,656,000$ & $1,665,146,000$ & $1,996,770,000$ \\
Dashen & $1,407,828,000$ & $1,811,106,000$ & $2,373,625,000$ \\
Addis & $112,313,000$ & $153,507,000$ & $199,693,000$ \\
Awash & $1,879,999,000$ & $2,722,421,000$ & $3,869,322,000$ \\
\hline
\end{tabular}

Table 23. Earning asset.

\begin{tabular}{llll}
\hline Earning assets & $\mathbf{2 0 1 7}$ & $\mathbf{2 0 1 8}$ & $\mathbf{2 0 1 9}$ \\
\hline Abay & $6,329,711,000$ & $8,823,133,000$ & $11,337,889,000$ \\
Abyssinia & $19,214,641,000$ & $24,186,090,000$ & $31,256,878,000$ \\
Dashen & $26,272,721,000$ & $33,287,430,000$ & $44,757,134,000$ \\
Addis & $2,227,535,000$ & $2,865,869,000$ & $3,751,377,000$ \\
Awash & $29,473,027,000$ & $39,622,204,000$ & $58,752,140,000$ \\
\hline
\end{tabular}

Table 24. Non-performing loan.

\begin{tabular}{llll}
\hline NPL & $\mathbf{2 0 1 7}$ & $\mathbf{2 0 1 8}$ & $\mathbf{2 0 1 9}$ \\
\hline Abay & $67,836,000$ & $198,181,000$ & $230,599,000$ \\
Abyssinia & $195,151,000$ & $234,579,000$ & $826,238,000$ \\
Dashen & $625,326,000$ & $795,657,000$ & $975,791,000$ \\
Addis & $4,992,000$ & $41,815,000$ & $136,192,000$ \\
Awash & $437,163,000$ & $582,879,000$ & $628,405,000$ \\
\hline
\end{tabular}

Table 25. Total equity.

\begin{tabular}{llll}
\hline TE & $\mathbf{2 0 1 7}$ & $\mathbf{2 0 1 8}$ & $\mathbf{2 0 1 9}$ \\
\hline Abay & $1,307,068,000$ & $1,803,479,000$ & $2,457,452,000$ \\
Abyssinia & $3,339,903,000$ & $4,245,359,000$ & $4,950,386,000$ \\
Dashen & $5,230,420,000$ & $5,866,611,000$ & $5,846,780,000$ \\
Addis & $753,546,000$ & $897,058,000$ & $1,111,635,000$ \\
Awash & $5,424,037,000$ & $6,495,714,000$ & $9,638,928,000$ \\
\hline
\end{tabular}

\section{References}

[1] Kieso, D. E., Weygandt, J. J., \& Warfield, T. D. (2007). Intermediate Accounting (12th ed.). Hoboken, NJ: John Wiley \& Sons, p. 1320 ISBN 0-471-74955-9.

[2] Eshna, V. (2020). Financial Performance, Understaning its concepts and importance. Retrived from https://www.simplilearn.com/financial-performance-rar21article.

[3] Andualem, S. (2013). Ethiopia's Awash International Bank: growth amid challenges.

[4] Corporate Finance Institute. (2017). Top banks in Ethiopia: overview of Ethiopia's leading financial institutions.

[5] Teshome, M. (2015). Evaluating the Financial Performance of Ethiopian Banks Using Financial Indicators-A Case Study on Dashen Bank.

[6] kiran, K. (2018 ). A CAMEL model analysis of selected public and private sector banks in india;. international journal of management, IT and engineering,, vol. 8 issue 8. 
[7] Aguenaous, Lahrech. A, bounakaya s,. (2017). analyzing the banks efficiency as a measurement of performance in the Moroccan context: application of CAMEL frame work: international review of research in emerging markets and global economy 2017, volume 3, issue 1.

[8] Chowdhury. T. S. (2019). a comparative study of profitability analysis in bankng sector of Bangladesh: Global journal of management and business research: administration and management, volume 19 , issue 8 .

[9] Abdullah M,(2015). An empirical analysis of liquidity, profitability and solvency of Bangladesh banks:. journal of business and financial affairs.

[10] Ali, M. (2016). bank profitability and its determinants in Pakistan: a panel data analysis after financial crisis;. journal of finance and economic research;, volume 1, issue 1.

[11] Trofimov, Ivan. D, etal. (2018). Determinants of commercial banks profitability in Malaysia: Munich personalRePEC Archive.

[12] Uniform Financial Institutions Rating System (UFIRS) (1996) FDIC Law, Regulations, Related Acts. 